\title{
RETHINKING THE RULE OF REASON: FROM PROFESSIONAL ENGINEERS TO NCAA
}

In National Society of Professional Engineers v. United States, ${ }^{1}$ the Supreme Court struck down an association's canon of ethics on antitrust grounds. In retrospect, the invalidation of a canon of ethics prohibiting competitive bidding for engineering work seems unremarkable and clearly correct. ${ }^{2}$ The importance of the opinion lies in its reformulation of the rule of reason, the traditional means of evaluating an alleged restraint of trade under the antitrust laws. With broad language, the Court presented an unqualified defense of competition, foreclosed consideration of factors other than the restraint's impact on competition, and reduced the rule of reason inquiry to "whether the challenged agreement is one that promotes competition or one that suppresses competition." 3

A rule of reason that is solely concerned with balancing the procompetitive and anticompetitive effects of an agreement lends itself to the majority of commercial arrangements. There are, however, a number of areas where this rule of reason lacks the flexibility necessary to deal with atypical situations and entities. ${ }^{4}$ This note will review the Professional Engineers decision and discuss three areas of difficulty encountered by the lower courts in attempting to apply the rule of reason as set out in Professional Engineers.

In the first of these areas, the lower courts have rigidly applied Professional Engineers to reach results that are analytically confusing and undesirable when taken to their logical conclusion. A typical case exhibiting this rigid approach is an antitrust challenge to the National Football League's player draft. ${ }^{5}$ The second situation finds the lower courts ignoring the Professional Engineers formulation of the rule of reason in favor of a different standard because of problems associated with applying the Professional Engineers test. Illustrating this avoidance

1. 435 U.S. 679 (1978).

2. Much of the initial novelty of the decision concerned the application of the antitrust laws to the learned professions. See infra note 20. Absent these considerations, holding an entire industry's outright ban on competitive bidding unlawful is not a surprising result.

3. Professional Eng'rs, 435 U.S. at 691.

4. For commentators noting the excessive rigidity of Professional Engineers, see Handler, Antitrust-1978, 78 CoLUM. L. REv. 1363, 1374-75 (1978); Robinson, Recent Antitrust Developments-1979, 80 CoLUM. L. Rev. 1, $16-19$ (1980); Zelek, Stern \& Dunfee, A Rule of Reason Decision Model After Sylvania, 68 CAL1F. L. REv. 13, 38-41 (1980) [hereinafter cited as Zelek].

5. See infra notes $37-73$ and accompanying text. 
of the Professional Engineers approach are cases involving antitrust challenges to the practices of sports associations. ${ }^{6}$ Finally, the lower courts have struggled to adapt the Professional Engineers rule of reason to situations not lending themselves to such a test. This has resulted in a strained attempt to force the cases into the Professional Engineers formula and in the application of tests not wholly consistent with Professional Engineers. Cases involving antitrust challenges to hospital staff privilege decisions illustrate this aspect of the problem. ${ }^{7}$

After exploring these difficulties, this note will suggest alternative methods of analysis to rectify them. ${ }^{8}$ These alternatives are based on aspects of the Professional Engineers decision that are not prominent in the opinion. Primary among these is the possibility of using an ancillary restraint test that assesses whether the challenged restraint is narrowly tailored to obtain acceptable ends. The Supreme Court's recent decision in NCAA v. Board of Regents ${ }^{9}$ took faltering steps toward adoption of such an ancillary restraint test, but ultimately did not utilize the opportunity to clarify the scope of the rule of reason as applied to atypical situations. ${ }^{10}$

\section{NATIONAL SOCIETY OF PROFESSIONAL ENGINEERS V. UNITED STATES}

The basic problem in interpreting and administering the Sherman Act is that it cannot mean what it literally says. Section 1 of the statute purports to outlaw every contract that restrains trade or commerce."11 Read literally, the statute would abrogate all of private contract law, for, as Justice Brandeis observed early in the process of interpreting the Act, "[e]very agreement concerning trade, every regulation of trade, restrains. To bind, to restrain, is of their very essence."12

The courts were therefore left the task of giving shape to the broad

\footnotetext{
6. See infra notes 74-94 and accompanying text.

7. See infra notes $95-117$ and accompanying text.

8. See infra notes $118-41$ and accompanying text.

9. 104 S. Ct. 2948 (1984).

10. See infra notes $142-93$ and accompanying text.

11. Section 1 of the Sherman Act provides in pertinent part:
}

Every contract, combination in the form of trust or otherwise, or conspiracy, in restraint of trade or commerce among the several states, or with foreign nations, is declared to be illegal.

15 U.S.C. $\S 1$ (1982).

12. Chicago Bd. of Trade v. United States, 246 U.S. 231, 238 (1918); see also Professional Eng'rs, 435 U.S. at $687-88$ ("restraint is the very essence of every contract"). 
mandate of the Sherman Act. ${ }^{13}$ The rule of reason is the tool that has traditionally been employed to give the Act definition and flexibility. ${ }^{14}$ Not every contract restraining trade is unlawful, but only those "unreasonably restrictive of competitive conditions." 15 In evaluating a challenged agreement under the rule of reason, the courts have long been directed to analyze "the facts peculiar to the business, the history of the restraint, and the reasons why it was imposed"16 to determine whether competition is unreasonably restrained.

The Supreme Court's most recent examination of the proper considerations under the rule of reason is its 1978 decision, National Society of Professional Engineers v. United States. ${ }^{17}$ As part of its code of ethics, the National Society of Professional Engineers adopted a canon prohibiting the submission or solicitation of engineering proposals on the basis of competitive bidding. ${ }^{18}$ An engineer was not to discuss or negotiate the question of fees until after a prospective client had selected him for a particular project. ${ }^{19}$ The United States brought a civil antitrust action challenging the association's canon prohibiting competitive bidding. ${ }^{20}$

The society attempted to justify its canon by arguing that the restriction on competitive bidding was reasonable because competition among

13. Professional Eng'rs, 435 U.S. at 688 (legislative history of Sherman Act indicates Congress expected the courts to fill in the contours of the statute (citing 21 Cong. Rec. 2456 (1890) (comments of Sen. Sherman))).

14. See id.

15. Standard Oil Co. v. United States, 221 U.S. 1, 58 (1911) (emphasis added).

16. Professional Eng'rs, 435 U.S. at 692; see Chicago Bd. of Trade v. United States, 246 U.S. 231,238 (1918).

17. 435 U.S. 679 (1978).

18. Id. at 683 n.3.

19. Id. at 682 .

20. While it was at one time thought that the antitrust laws did not apply to the learned professions, the Supreme Court put the so-called learned profession exemption to rest in Goldfarb v. Virginia State Bar, 421 U.S. 773, 793 (1975) (local bar association's "minimum fee schedule" for title examination violates section 1 of Sherman Act). In so doing, the Court noted that professional practices may still be subject to a somewhat different antitrust analysis than ordinary business activities. The now famous footnote 17 in Goldfarb provides:

The fact that a restraint operates upon a profession as distinguished from a business is, of course, relevant in determining whether that particular restraint violates the Sherman Act. It would be unrealistic to view the practice of professions as interchangeable with other business activities, and automatically to apply to the professions antitrust concepts which originated in other areas. The public service aspect, and other features of the professions, may require that a particular practice, which could properly be viewed as a violation of the Sherman Act in another context, be treated differently.

Id. at $788 \mathrm{n} .17$.

Professional Engineers is notable for its statement that this cautionary note in Goldfarb "cannot be read as fashioning a broad exemption under the Rule of Reason for learned professions." 435 U.S. at 696 . The Court made it clear that a total ban on competitive bidding and price information is no more defensible in the professional context than it would be in the commercial context. 
engineers is contrary to the public interest. ${ }^{21}$ It claimed that competitive pressure to offer engineering services at the lowest possible price would adversely affect the quality of engineering and would therefore be dangerous to public health, safety, and welfare. ${ }^{22}$ The Court rejected this defense as resting on a fundamental misunderstanding of the rule of reason. ${ }^{23}$ In response, the Court undertook a review and reformulation of the rule of reason. Certain practices are so plainly anticompetitive that they are condemned as illegal per se without an elaborate study of the industry. ${ }^{24}$ Practices falling into this category include price fixing, market division among competitors, tying arrangements, and group boycotts. ${ }^{25}$ Practices not subject to per se condemnation are evaluated under the rule of reason.

The Court noted that, contrary to its name, the rule of reason does not open the antitrust inquiry to defense of a chailenged restraint simply on grounds that it falls within the realm of reason. ${ }^{26}$ It is not enough that some argument can be made that a restraint is desirable. Instead, the rule of reason analysis must focus on the restraint's impact on competition. ${ }^{27}$ The Court thoroughly rejected the society's defense that its restraint was reasonable because competition among engineers is contrary to the public interest. ${ }^{28}$ It emphasized that the Sherman Act is premised on a belief that competition is the preferred means of allocating resources. ${ }^{29}$ The Court bluntly concluded that "the Rule of Reason does not support a defense based on the assumption that competition itself is unreasonable." 30 Courts may not entertain arguments that monopolistic arrangements are preferable to competition because of the special characteristics of a particular industry. ${ }^{31}$ Any industry believing competition to

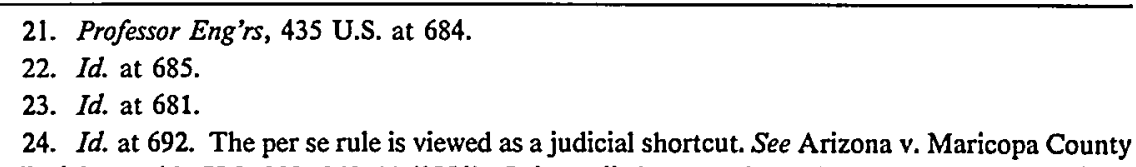
Medical Soc'y, 457 U.S. 332, 343-44 (1981). It is applied to practices whose effects on competition are so pernicious, so plainly anticompetitive and lacking in redeeming virtue, that they will be condemned on their face. See Professional Eng'rs, 435 U.S. at 692; Northern Pac. Ry. v. United States, 356 U.S. 1,5 (1958). When it is determined that the per se rule is applicable, no further inquiry is made, and no justification for the restraint will be heard. See Maricopa County, 457 U.S. at 351.

25. See Arizona v. Maricopa County Medical Soc'y, 457 U.S. 332, 344 n.15 (1981). Whether a particular practice falls within one of these categories is often not easily determined and is the subject of frequent litigation. See, e.g., id. at 336-37; Broadcast Music, lnc. v. CBS, 441 U.S. 1, 4 (1978); Continental T.V., Inc. v. GTE Sylvania Inc., 433 U.S. 36, 57 (1977).

26. Professional Eng'rs, 435 U.S. at 688.

27. Id.

28. Id. at 693-95.

29. Id. at 695 .

30. Id. at 696.

31. Id. at 689. 
be unsuitable to it was directed to petition Congress for an exemption to the Sherman Act. ${ }^{32}$

In the Court's words, "the inquiry mandated by the Rule of Reason is whether the challenged agreement is one that promotes competition or one that suppresses competition." 33 The rule of reason test called for in Professional Engineers apparently requires a court to balance the procompetitive effects of a challenged agreement against its anticompetitive effects to determine which predominates. ${ }^{34}$ No factor other than the restraint's effect on competition may be considered and only restraints with a net procompetitive effect are permissible. ${ }^{35}$

\section{APPlication of the PROFESSIONAL ENGINEERS RULE of REASON}

Professional Engineers' call to focus solely on a balancing of anticompetitive and procompetitive effects in the rule of reason analysis causes problems in several contexts. These problems often arise when the practice challenged on antitrust grounds is intended primarily, or at least partially, to effect noneconomic goals. The party attempting to defend an agreement or practice by pointing to the achievement of these noneconomic goals is confronted with Professional Engineers' admonition that only benefits to competition can be considered to offset a restraint of trade.

Applying the rule of reason, as articulated in Professional Engineers, also proves troublesome when entities with unusual characteristics are involved. This can occur when the entity is largely self-regulating or when the model of free competition does not apply to the entity in-

32. Id. at 689-90.

33. Id. at 691.

34. See, e.g., Smith v. Pro Football, Inc., 593 F.2d 1173, 1183 (D.C. Cir. 1978). As one commentator has described the Professional Engineers test, the restraint must be "output expanding" rather than "output restricting." Kissam, Webber, Bigus \& Holzgraefe, Antitrust and Hospital Privileges: Testing the Conventional Wisdom, 70 CALIF. L. REv. 595, 646 (1982) [hereinafter cited as Kissan \& Webber] (citing Elzinga, The Compass of Competition for Professional Services, in REGULating the Professions 107 (R. Blair \& S. Rubin eds. 1980)).

35. Justice Blackmun, with whom Justice Rehnquist joined, concurred in the judgment, but would not have reached as far as the Court in intimating that any ethical rule with a net anticompetitive effect is forbidden. Professional Eng'rs, 435 U.S. at 699. He noted that the case did not require the Court to decide whether the rule of reason could ever take account of benefits other than increased competition. Id. (Blackmun, J., concurring in the judgment). Of concern to him was the fact that there may be ethical rules that have more than a de minimis anticompetitive effect yet are important and necessary. Id. at 700 . Examples given were a medical association's standards of minimum competency for licensing or a bar association's regulation of certain advertising or inperson solicitation. Id. at 700-01. Justice Blackmun felt that the approach indicated in the Goldfarb footnote, see supra note 20, left the Court enough flexibility to deal with such situations. Id. at 699 . 
volved. ${ }^{36}$ The lower courts have found it difficult to fit these situations within the rule of reason framework mandated by Professional Engineers.

\section{A. Rigid Application of Professional Engineers.}

An early example of a court grappling with the Professional Engineers rule of reason is Smith v. Pro Football, Inc. ${ }^{37}$ Smith involved an antitrust challenge to the National Football League (NFL) player selection system, or draft. The draft is the means by which negotiation rights to graduating college football players are allocated among the NFL clubs. It is one of the various mechanisms employed by the league to limit the movement of players between teams. ${ }^{38}$ The draft is designed to promote competitive balance between the teams in the league by dispersing new player talent. ${ }^{39}$ The weaker teams have a selection preference as selections are made in reverse order of the prior year's standings. ${ }^{40}$ The goal is to have evenly matched teams, in the hope of creating closer games, tight pennant races, and the uncertainty of outcome that makes for spectator interest. ${ }^{41}$

36. The Sherman Act is premised on the belief that competition is the best method of allocating resources and that the free market, operating without restraint, will ultimately produce lower prices and better goods and services. See id. at 695. This view is consistent with analyzing an agreement to determine whether it promotes or suppresses competition. Id. at 691 . This model of market competition is, however, not always applicable. For instance, a large law firm may have several branch offices. We would not expect each office to compete against the others in the market to hire graduating law students, but would anticipate a coordinated recruiting strategy. This could well involve an agreement that each office will pay the same starting salary, rather than bid against each other. If a number of separate law firms came to such an agreement, there would be little hesitancy in finding such an agreement to constitute price fixing. The same agreement, solely among branches of the same firm, would merely entail fixing the firm's starting salary. See R. BORK, THE ANTIrRUST PARADOX 265 (1978); see also Broadcast Music, Inc. v. CBS, 441 U.S. 1, 9 (1978) (when two partners set the price of the goods they sell they are literally price fixing, but it is not per se illegal); Grauer, Recognition of the National Football League as a Single Entity Under Section 1 of the Sherman Act: Implications of the Consumer Welfare Model, 82 MicH. L. REv. 1, 4-5 (1983) (noting absurdity of hypothetical action by young attorney alleging that the partners of his law firm conspired to fix associate's salaries in violation of section 1 of the Sherman Act by not allowing departments within the firm to bid for associate's services). This basic premise, that the entities involved are competitors, goes unstated in Professional Engineers.

Between the extremes of free market competitors and branches of a single entity lie variant entities. These entities consist of separate, individual components that must cooperate in order to function and produce a joint product. Applying the Professional Engineers rule of reason to such entities has proven troublesome and is the focus of much of this note.

37. 593 F.2d 1173 (D.C. Cir. 1978).

38. See J. Weistart \& C. Lowell, THe Law of Sports $\S 5.03$ (1979).

39. Smith, 593 F.2d at 1175.

40. Id.

41. Id. at 1176. Most commentators recognize that the success of a league sports venture depends upon the unpredictability of the outcome. See, e.g., J. WEISTART \& C. LowELL, supra note $38, \S 5.07$, at $595-96$. 
Under the version of the draft challenged by Smith, ${ }^{42}$ only one team could select any particular college player. If a player could not reach a contract agreement with that team, he could not play in the NFL at all. ${ }^{43}$ The district court held the draft to be illegal per se. ${ }^{44}$ The court found that the draft's restrictions were " 'naked restraints of trade with no purpose except stifling of competition." "45 In the alternative, the court held that the draft would also be unlawful if judged under the rule of reason. ${ }^{46}$

The Court of Appeals for the District of Columbia Circuit took a more tolerant view of the draft, rejecting the district court's conclusion that the draft was illegal per se. ${ }^{47}$ Several reasons were advanced for this conclusion. The court noted that the NFL clubs operate in some respects like a joint venture to deliver a product that could not be produced without agreement and joint action. ${ }^{48}$ Courts have consistently refused to invoke the per se rule where the peculiar characteristics of an industry necessitate cooperation and concerted activity. ${ }^{49}$ The court emphasized that the draft could not properly be characterized as having "no purpose except stifling of competition." 50 Some form of player selection system might be needed to regulate competition in what would otherwise be a chaotic bidding market for college players. ${ }^{51}$ Considerable evidence was also presented by the NFL to show that the draft was designed to, and did, contribute to preserving playing-field equality among the NFL clubs. ${ }^{52}$ Further, the court noted that a draft was widely used in all major professional sports and had both judicial and scholarly support for its economic usefulness. ${ }^{53}$

After deciding that the rule of reason was appropriate, the court undertook to apply it. The court looked to the test it believed was

42. As a result of collective bargaining with the players, the league has made several modifications to the draft system subsequent to Smith's suit. See Smith, 593 F.2d at 1176 n.6.

43. Id. at 1187.

44. Smith v. Pro Football, Inc., 420 F. Supp. 738, $744-45$ (D.D.C. 1976), aff'd in part and rev'd in part, 593 F.2d 1193 (D.C. Cir. 1978). For an explanation of the role of the per se rule in antitrust analysis, see supra notes 24-25 and accompanying text.

45. Smith, 420 F. Supp. at 745 (quoting White Motor Co. v. United States, 372 U.S. 253, 263 (1963)).

46. $I d$.

47. Smith, 593 F.2d at 1178 .

48. Id. at 1179 .

49. Id. at 1180; see NCAA v. Board of Regents, 104 S. Ct. 2948, 2961 (1984); Hatley v. American Quarter Horse Ass'n, 552 F.2d 646, 652-53 (5th Cir. 1977); Worthen Bank \& Trust Co. v. National Bank-Americard, Inc., 485 F.2d 119, 126, 128 n.7 (8th Cir. 1973), cert. denied, 415 U.S. 918 (1974).

50. Smith, 593 F.2d at 1181 .

51. Id.

52. Id.

53. Id. at 1182. 
enunciated in Professional Engineers : a balancing of the anticompetitive evils of the challenged practice against its procompetitive virtues. ${ }^{54}$ If the net effect of the restraint was to impede competition, it would be held to be unreasonable..$^{55}$

The court had no difficulty in ascertaining the relevant anticompetitive evils. The draft restricted competition among NFL clubs for the services of college players. ${ }^{56}$ Indeed, that was its purpose. It forced each seller of such services to deal with only one buyer, removing the seller's bargaining power. 57 The court found that the effect of this was to lower the salary levels of graduating college players. 58

The court then turned to the NFL's justification for the draft. Because it had already recognized the special needs of the industry and the value of a draft in promoting those needs, ${ }^{59}$ one would think that the court might give weight to these factors under the rule of reason. The court, however, believed that the virtues of the draft, enumerated and considered in refusing to apply the per se rule, could no longer be taken into account under the rule of reason because they did not promote economic competition. ${ }^{60}$

In the court's view competitive balance and playing-field equality among the teams may heighten athletic competition, and therefore have a "procompetitive" effect on the playing field, but this does not increase competition in the economic sense. ${ }^{61}$ The court noted that competition would not be increased in the sense of increased market entry or lower prices. ${ }^{62}$ Illustrative of its inability to fit the facts of this case into the Professional Engineers framework is the court's statement that because 'the draft's 'anticompetitive' and 'procompetitive' effects are not comparable, it is impossible to 'net them out' in the usual rule-of-reason balancing." ${ }^{3}$ The court stated that in "strict economic terms, the draft's demonstrated procompetitive effects are nil." 64 With nothing of procompetitive virtue to balance, "the outcome is plain," and the draft was held

54. Id. at 1183.

55. Id.

56. Id. at 1185 .

57. Id.

58. Id. at 1186.

59. See supra notes $48-53$ and accompanying text.

60. Smith, 593 F.2d at 1186; see Robinson, supra note 4, at $20-22$ (noting absurdity of considering draft's virtues in order to avoid per se condemnation only to foreclose such factors from rule of reason analysis).

61. Smith, 593 F.2d at 1186.

62. Id.

63. Id.

64. Id. 
to violate the rule of reason. ${ }^{65}$ Thus, the court had reached the anomalous result that the league's justification for the draft was taken into account in refusing to apply the per se rule, but could not be considered under the rule of reason. ${ }^{66}$

The inconsistency of the court's analysis is highlighted by its discussion of less restrictive forms of player draft that might be acceptable. The league's need for some form of player draft was not entirely lost on the court. It noted that this case involved what amounted to a "total ban" on competition, ${ }^{67}$ but suggested several significantly less anticompetitive versions of a draft system, ${ }^{68}$ although purporting not to intimate any view as to their legality. ${ }^{69}$ The court seemed to believe that some less restrictive form of draft system was capable of withstanding antitrust scrutiny. ${ }^{70}$

The court's proposals, however, fail to withstand its own rule of reason analysis. Any less restrictive draft would still limit the ability of certain players to contract with certain teams. An anticompetitive effect would clearly exist. The justification for a draft system, even a less restrictive one, would remain the league's need for competitive balance. According to the court, however, a competitive balance justification cannot be considered because it is not an economically procompetitive justification. ${ }^{71}$ The result of such an analysis is the condemnation of any form of player draft. ${ }^{72}$ The court had thus painted itself into an

65. Id. at 1187.

66. See Robinson, supra note 4, at 20-22.

67. Smith, 593 F.2d at 1187.

68. The court suggested allowing more than one team to draft a player, holding a second yearly draft for players unable to reach agreement with the first drafting club, or subjecting only the best college players to the draft. Id. at 1188 .

69. Id. at 1187.

70. See also Mackey v. National Football League, 543 F.2d 606, 623 (8th Cir. 1976) (reasonable restrictions relating to player transfers may be necessary for successful operation of the league; every restraint on competition for player services not necessarily violative of antitrust laws), cert. dismissed, 434 U.S. 801 (1977); J. WeIsTART \& C. LowELL, supra note 38, § 5.07, at 622-25 (reasonable accommodation of competing concerns likely to involve some restraints on player mobility).

71. Smith, 593 F.2d at 1186; see supra notes 61-65 and accompanying text.

72. Despite the decision in Smith, the NFL still employs a player draft. The player draft, and other restrictions on player mobility, have been agreed to by the NFL player's union and incorporated into the collective bargaining agreement between the league and the union. See Alexander v. National Football League, 1977-2 Trade Cas. (CCH) \ 61,730, at 72,985, 72,997 (D. Minn.), aff'd sub nom. Reynolds v. National Football League, 584 F.2d 280 (8th Cir. 1978). The draft exists today because player restraints are incorporated into a labor agreement as a result of good faith, arm's length bargaining, and are therefore exempt from the antitrust laws under the nonstatutory labor exemption. See McCourt v. California Sports, Inc., 600 F.2d 1193, 1203 (6th Cir. 1979); see also Weistart, Judicial Review of Labor Agreements: Lessons From the Sports Industry, 44 LAW \& CONTEMP. ProBs. 109, 109-33 (1981) (historical overview of labor exemption in context of sports antitrust litigation). For general background on the nonstatutory labor exemption, see J. WEISTART \& C. LowELL, supra note $38, \S 5.04$. 
analytical corner, conceding the league's valid interest in competitive balance, but precluding any consideration of this factor in the rule of reason analysis. ${ }^{73}$

\section{B. Ignoring the Professional Engineers Approach: The Exclusionary Practices of Sports Associations.}

In a wide variety of situations, associations that govern, regulate, and promote particular activities make determinations that affect the eligibility of participants and acceptability of equipment. ${ }^{74}$ Examples of association decisions recently subjected to litigation include a tennis association's refusal to sanction a new type of racket ${ }^{75}$ and an association's refusal to register a horse because its markings did not conform to

The fact that restraints to which a union has agreed may be exempt from the antitrust laws does not moot the significance of the discussion of the Smith case. The basic difficulty in applying the Professional Engineers competitive balancing test remains. Further, the point is not moot even as to a player draft. The recently formed United States Football League (USFL) conducts a player draft. There is no collective bargaining agreement in the USFL to insulate the player draft from antitrust attack. The USFL could conceivably face litigation very similar to the Smith case in the near future.

73. Prior to Professional Engineers, several antitrust actions had been brought challenging sports league practices tending to restrict the mobility of players. See, e.g.. Mackey v. National Football League, 543 F.2d 606 (8th Cir. 1976), cert. dismissed, 434 U.S. 801 (1977). In Mackey, a player challenged the NFL's Rozelle Rule. The Rozelle Rule, or free agent compensation scheme, was a system whereby the league commissioner would award compensation to the team losing a player whose contract term had expired. See J. WeISTART \& C. LowELL, supra note $38, \S 5.03$, at 502-03. The compensation came from the team signing the free agent and would typically consist of draft choices and/or players from the signing team's roster. Id. The presence of the Rozelle Rule drastically inhibited bidding for the services of free agents. Id. at 503 .

Mackey brought an antitrust challenge to the Rozelle Rule. The Court of Appeals for the Eighth Circuit held that the per se rule would not be applied and turned to a rule of reason analysis. Mackey, 543 F.2d at 619-20. Unencumbered by the Professional Engineers opinion, the test applied was whether the restraint was justified by legitimate business purposes and no more restrictive than necessary. Id. at 620 . The court found that the league had a legitimate business interest in maintaining competitive balance between the teams in the league. Id. at 621 . The Rozelle Rule was nonetheless invalidated because it was more restrictive than necessary to serve this legitimate goal. $I d$. at 622. This approach left room for the possibility that the league could employ less restrictive means to limit player movement without violating the antitrust laws. Id. at 623 .

This analysis should be compared to that employed in the Smith case. Because of Professional Engineers, the Smith court felt unable to give weight to the league's business justifications for the player draft under the rule of reason. See supra notes 59.66 and accompanying text. This left the court in an analytical bind. The draft in question amounted to a "total ban" on competition, and therefore would have been held unlawful under either the Mackey or Smith approach. However, when the Smith court suggested less restrictive versions of the draft in order to meet the NFL's legitimate business needs, it did so in the face of a rule of reason analysis that could not uphold any form of player draft because of a complete lack of procompetitive benefits. See supra notes 67-72 and accompanying text.

74. See generally J. WeISTART \& C. LowELL, supra note $38, \S 5.10$.

75. Gunter Harz Sports, Inc. v. United States Tennis Ass'n, 511 F. Supp. 1103 (D. Neb.), aff'd per curiam, 665 F.2d 222 (8th Cir. 1981). 
specifications. ${ }^{76}$ In such cases, the disappointed applicant or manufacturer may challenge the exclusion on antitrust grounds. ${ }^{77}$ Similar issues are raised when a previously eligible participant is declared ineligible for reasons of misconduct. ${ }^{78}$ Courts faced with these challenges have generally refused to apply the per se rule 79 because, by definition, the activities require collective action and rulemaking. Further, the rules in question are typically not naked restraints of trade with no redeeming virtue, but are obviously intended to effect some other valid goal.

Thus, these sports association practices have been evaluated under the rule of reason when challenged on antitrust grounds. The question is how the rule of reason analysis should proceed. Professional Engineers apparently requires a balancing of procompetitive and anticompetitive effects. The cases involving sports association regulations have not taken this approach, nor have they explained the failure to do so. Instead, the cases apply a test deemed appropriate for industries where a need for selfregulation is apparent. ${ }^{80}$ This inquiry focuses on:

(1) whether the collective action is intended to accomplish an end consistent with the policy justifying self-regulation; (2) whether the action is reasonably related to that goal; (3) whether such action is no more extensive than necessary; and (4) whether the association provides procedural safeguards which assure that the restraint is not arbitrary and which furnish a basis for judicial review. ${ }^{81}$

76. Hatley v. American Quarter Horse Ass'n, 552 F.2d 646 (5th Cir. 1977).

77. See, e.g., Bridge Corp. of Am. v. American Contract Bridge League, Inc., 428 F.2d 1365, 1365-66 (9th Cir. 1970) (sanctioning organization refused to allow use of new computer system for scoring bridge tournaments), cert. denied, 401 U.S. 940 (1971); Deesen v. Professional Golfers Ass'n, 358 F.2d 165, 166 (9th Cir.) (golfer denied eligibility to play in PGA tournaments), cert. denied, 385 U.S. 846 (1966); STP Corp. v. United States Auto Club, 286 F. Supp. 146, 149 (S.D. Ind. 1968) (sanctioning organization guidelines excluding certain turbine powered cars).

78. See, e.g., Cokin v. American Contract Bridge League, Inc., 1983-1 Trade Cas. (CCH) If 65,367 (S.D. Fla. 1981) (bridge player expelled for improper prearranged communications); Cooney v. American Horse Shows Ass'n, 495 F. Supp. 424, 426-28 (S.D.N.Y. 1980) (horse trainer suspended when horse found to have been drugged).

79. See Hatley v. American Quarter Horse Ass'n, 552 F.2d 646, 652 (5th Cir. 1977); Gunter Harz Sports, Inc. v. United States Tennis Ass'n, 511 F. Supp. 1103, 1115-16 (D. Neb.), aff'd per curiam, 665 F.2d 222 (8th Cir. 1981).

80. See Gunter Harz Sports, Inc. v. United States Tennis Ass'n, 511 F. Supp. 1103, 1116 (D. Neb.), aff'd per curiam, 665 F.2d 222 (8th Cir. 1981). This line of reasoning is more or less derived from Silver v. New York Stock Exch., 373 U.S. 341 (1963). See Gunter Harz Sports, 511 F. Supp. at 1116.

81. Gunter Harz Sports, Inc. v. United States Tennis Ass'n, 511 F. Supp. 1103, 1116 (D. Neb. 1981); see also United States Trotting Ass'n v. Chicago Downs Ass'n, 665 F.2d 781, 790 (7th Cir. 1981) (test will be whether the challenged conduct went beyond the level of restraint reasonably necessary to accomplish whatever legitimate business purpose is asserted for $i t)$; J. WEISTART \& C. LowELL, supra note $38, \S 5.10$, at $670-71$ (activities of sports associations scrutinized by examining purpose of rule in question, whether rule is proper means of achieving justifiable end, and procedural aspects of activity). 
A recent case illustrates the difference between these two approaches. In Gunter Harz Sports, Inc. v. United States Tennis Association, 82 a manufacturer of "double-strung" tennis rackets brought an antitrust challenge to the International Tennis Federation's rule defining tennis rackets in such a way as to exclude double-strung rackets. ${ }^{83}$ The rule, adopted after considerable study of the effect such rackets would have on the game of tennis, ${ }^{84}$ was intended to eliminate rackets that place undue spin on the ball. A qualifying procedure was specified by which rackets that did not meet the letter of the rule could still be approved if they did not materially alter the flight of, or add significant spin to, the ball. ${ }^{85}$

The court rejected a holding of per se illegality and concluded that the rule of reason should be employed. ${ }^{86}$ It then applied the four-part test set out above. ${ }^{87}$ The court found that the goal of preserving the essential character and integrity of the game of tennis as it had always been played was a legitimate goal for the association to adopt. ${ }^{88}$ The racket rule in question was reasonably related to that goal. ${ }^{89}$ The evidence supported the association's belief that double-strung rackets could fundamentally change the nature of the game.90 The rule was narrowly drawn to proscribe only rackets imparting extra spin, and the qualifying procedure for rackets not conforming to the face of the rule further narrowed its breadth. ${ }^{91}$ Finally, the court found that the association's

82. 511 F. Supp. 1103 (D. Neb.), aff'd per curiam, 665 F.2d 222 (8th Cir. 1981).

83. Id. at 1107. The rule provided:

The racket shall consist of a frame and a stringing. . . .

The frame may be of any material, weight, size or shape. . . .

The strings must be alternatively interlaced or bonded where they cross and each string must be connected to the frame.

If there are attachments, they must be used only to prevent wear and tear and must not alter the flight of the ball.

The density in the centre must be at least equal to the average density of the stringing. . . .

The spirit of this rule is to prevent undue spin on the ball that would result in a change in the character of the game.

The stringing must be made so that the moves between strings will not exceed what is possible for instance with 18 mains and 18 crosses uniformly spaced and interlaced in a stringing area of 75 square inches.

Id. at 1111 n.3. The United States Tennis Association, a member of the International Tennis Federation, also adopted the rule. Id. at 1107.

84. Id. at 1119-21.

85. Id. at 1109 n.2.

86. Id. at 1116 .

87. See supra text accompanying note 81.

88. Gunter Harz Sports, S11 F. Supp. at 1117.

89. Id. In reaching this decision the court noted that a high degree of deference would be shown to the judgment of the sanctioning organization. $I d$.

90. Id. at 1120-21.

91. Id. at 1121 . 
procedural safeguards, while not a model of due process, were adequate. ${ }^{92}$

In contrast to this approach, applying the Professional Engineers rule of reason test to the racket rule would present obvious problems. The racket rule has a clear anticompetitive effect in prohibiting a manufacturer from attempting to market its rackets to professional tennis players. The rule therefore excludes a potential competitor from a substantial market. ${ }^{93}$ On the other side of the Professional Engineers balance, an economically procompetitive justification for the rule is not readily apparent.

Preserving the character of the game of tennis as it has always been played does not increase competition in the economic sense. It might be a worthwhile goal that a sanctioning and promotional body should advance. It does not, however, increase economic competition in the sense of encouraging entrants into the market or lowering prices. ${ }^{94}$ The racket rule has an anticompetitive effect, no apparent economic procompetitive virtues to balance against it, and would therefore be struck down under a literal reading of Professional Engineers. This is not the result reached by the court, nor is it apparent that the Sherman Act was meant to prevent a recognized sanctioning organization from attempting to preserve the game of tennis in its traditional form, even if this creates an incidental restraint of trade.

\section{Struggling With the Professional Engineers Approach: Professional Regulation and Staff Privilege Cases.}

With the demise of the professional exemption to the antitrust laws, ${ }^{95}$ antitrust suits in the health care area, and, in particular challenges to the denial of hospital staff privileges, have increased in number. ${ }^{96}$ The typical case involves a physician who is refused the privilege to practice at a particular hospital, has his privileges revoked, or fails to win renewal of his hospital privileges. ${ }^{97}$ The physician may seek to redress the injury suffered by resort to the antitrust laws on a theory that

\footnotetext{
92. Id. at 1121-22.

93. This exclusion will in turn have a considerable impact on the marketability of the rackets to nonprofessional players.

94. See Smith v. Pro Football, Inc., 593 F.2d 1173, 1186 (D.C. Cir. 1978) (requiring economic procompetitive benefits such as encouraging entry or lower prices).

95. See supra note 20.

96. See Kissam, supra note 34, at 596, 599-600; see also Horan \& Nord, Application of Antitrust Law to the Health Care Delivery System, 9 CUM. L. Rev. 685, 688-700 (1979) (reviewing the status of the traditional defenses relied on by the health care industry and concluding that the defenses have received more restrictive application in recent years).
}

97. See, e.g., Pontius v. Children's Hosp., 552 F. Supp. 1352, 1356 (W.D. Pa. 1982). 
the refusal to allow him to practice at the hospital effectively reduces competition in the marketplace and is therefore a restraint of trade within the purview of section 1 of the Sherman Act. ${ }^{98}$ The hospital often defends its decision not to grant privileges on the basis of a concern for medical quality and the belief that it would be endangered by granting privileges. ${ }^{99}$

The basic conflict in these cases is to "reconcile arguments about medical quality with arguments about promoting competition." 100 The Professional Engineers decision complicates this problem with its admonition that the only relevant consideration in the rule of reason analysis is the effect on competition. ${ }^{101}$ The privilege cases undoubtedly involve restraints that have an anticompetitive effect. ${ }^{102}$ Physicians who are licensed to practice medicine are excluded from doing so in a particular place. Under a literal reading of Professional Engineers, the only valid justification that can be offered for a staff privilege decision is that it is procompetitive. ${ }^{103}$ It does not suffice to defend the decision with arguments of "public welfare" or "consumer protection."104 The language of Professional Engineers seems to condemn any decision with an "overall anticompetitive effect" and does not appear to allow for a consideration of medical quality. Nevertheless, the courts that have considered the denial of staff privileges have universally recognized the validity of a concern for medical quality. ${ }^{105}$ In fact, they conclude that, absent proof of an anticompetitive intent, proof that the defendant acted to establish

98. A physician with a practice that requires the use of hospital facilities is precluded from plying his trade if he is denied hospital privileges. As this eliminates a doctor from the marketplace and lessens competition among doctors, an antitrust violation may be alleged. In order to meet the contract or conspiracy requirement of section 1 of the Sherman Act, the party bringing the antitrust action typically alleges that the hospital and other doctors with staff privileges have entered into a conspiracy aimed at excluding him. See, e.g., Robinson v. Magovern, 521 F. Supp. 842, 848, 906 (W.D. Pa. 1981).

99. See, e.g., Pontius v. Children's Hosp., 552 F. Supp. 1352, 1359 (W.D. Pa. 1982).

100. Kissam \& Webber, supra note 34 , at 602 .

101. See supra notes 3, 26-35 and accompanying text.

102. See Robinson v. Magovern, 521 F. Supp. 842, 919 (W.D. Pa. 1981).

103. See Kissam \& Webber, supra note 34 , at 646 . The privilege decision must be "output expanding" rather than "output restricting" in order to pass muster under Professional Engineers. Id. (citing Elzinga, The Compass of Competition for Professional Services, in REgulating THE Profes. S1ONS 107 (R. Blair \& S. Rubin eds. 1980)).

104. Id. Similar arguments as to public health and safety were advanced by the National Society of Professional Engineers in defense of their restrictive canon. See supra notes 21-22 and accompa. nying text. These were rejected as outside the rule of reason. See supra note 23 and accompanying text.

105. See, e.g., Pontius v. Children's Hosp., 552 F. Supp. 1352, 1372 \& 1376 (W.D. Pa. 1982); Williams v. Kleaveland, 534 F. Supp. 912, 919 (W.D. Mich. 1981); Robinson v. Magovern, 521 F. Supp. 842, 919 (W.D. Pa. 1981). 
high quality standards is a persuasive antitrust defense. ${ }^{106}$

Several rationales have been advanced by the courts to reconcile this apparent inconsistency. One way in which courts have attempted to avoid this dilemma is to declare that an anticompetitive effect does not necessarily require antitrust condemnation if it is insubstantial. ${ }^{107}$ This, of course, does not square with the suggestion in Professional Engineers that a net anticompetitive effect will not be tolerated. ${ }^{108}$ Illustrative of this approach is Pontius v. Children's Hospital, ${ }^{109}$ where a hospital's decision not to reappoint a physician to the staff was attacked on antitrust grounds. The hospital contended that the decision not to reappoint was based on a number of factors, including incompetence, an excessive mortality rate among patients, unnecessary operations, and an inability to cooperate with other surgeons and staff. ${ }^{110}$ Giving credence to the notion that an insubstantial anticompetitive effect will not be fatal, the court stated: "We do not believe that the Sherman Act prevents a hospital from discharging a physician it believes incompetent regardless of any collateral effect on 'competition." "111 The court satisfied itself that the hospital's reasons were supported by substantial evidence and that the procedures followed by the hospital in making its determinations were elaborate. ${ }^{112}$

Another method has been employed to reconcile a court's desire to take account of medical quality concerns with the Professional Engineers balancing of competitive effects. Under this approach, the court nominally applies the Professional Engineers test, but attempts to convert the concern for medical quality into a procompetitive justification. Robinson v. Magovern, ${ }^{113}$ which also involved the denial of hospital staff privileges, is an example of this approach. The court reasoned that the hospital could properly take medical quality into account in its staffing decisions. By so doing, the hospital would seek to maintain the highest standards

106. Williams v. Kleaveland, 534 F. Supp. 912, 919 (W.D. Mich. 1981) ("[I]n the absence of an anticompetitive intent or purpose, proof that Defendants acted for the primary purpose of maintaining high quality care is a persuasive defense to an antitrust claim.").

The defense of maintaining high quality standards has also been recognized in cases challenging a physician's suspension for misconduct or violating rules intended to protect and benefit the public. See, e.g., Nara v. American Dental Ass'n, 526 F. Supp. 452, 457 (W.D. Mich. 1981).

107. See, e.g., Kreuzer v. American Academy of Periodontology, 558 F. Supp. 683, 685 (D.D.C. 1983), aff'd in part, rev'd in part, and remanded, 735 F.2d 1479 (D.C. Cir. 1984); Pontius v. Children's Hosp., 552 F. Supp. 1352, 1372 (W.D. Pa. 1981).

108. See supra notes $3,26-35$ and accompanying text.

109. 552 F. Supp. 1352 (W.D. Pa. 1982).

110. Id. at 1359 .

111. Id. at 1372 .

112. Id.

113. 521 F. Supp. 842 (W.D. Pa. 1981). 
and reputation for excellence. The hospital would therefore have enhanced its competitive position vis-à-vis other hospitals in the region, with vigorous competition among hospitals benefitting the public. ${ }^{114}$

Although this approach is consistent with the language of Professional Engineers, it requires a straining of reason that conceals the actual motivation for the result reached. The hospital cases would be far clearer were the Court to recognize openly the concern for medical quality and the legitimate business desire to avoid malpractice liability. ${ }^{15}$ A court would then be free to analyze the restraint in question by asking whether it is intended to effect a legitimate goal, whether it is unreasonably restrictive in doing so, and whether adequate procedural safeguards are provided. ${ }^{116}$ It would no longer be necessary to speculate whether some conceivable benefit to competition in the overall health care market out-

114. Id. at 919; see also Kissam \& Webber, supra note 34, at 646 (privilege decision must be part of plan to make hospital more competitive with other hospitals in the region); $c f$. Continental T.V., Inc. v. GTE Sylvania Inc., 433 U.S. 36, 54 (1977) (increase in interbrand competition can be balanced against decrease in intrabrand competition).

115. Similar issues are raised in a number of cases where a concern for safety and the avoidance of legal liability are cited as justifications for a restraining practice. In Tripoli Co. v. Wella Corp., 425 F.2d 932 (3d Cir.), cert. denied, 400 U.S. 831 (1970), a manufacturer of cosmetics and beauty products refused to sell its products to a long-time distributor when it was discovered that the distributor was reselling the products at retail, to end users, and not solely to professionals. This restriction on retail sale was defended on the ground that the products could be dangerous if applied by nonprofessionals who are not familiar with them. The court stated that whether the manufacturer was interested in protecting the public from harm or itself from potential product liability, either motive would be a sufficient lawful purpose "to which the restriction on resale . . . is reasonably ancillary." Id. at 938.

The Court in Professional Engineers cited Wella as a proper application of the rule of reason, explaining that the marketing restraint was reasonably ancillary to the seller's main purpose and had no anticompetitive effect. 435 U.S. at 696 n.22 (emphasis added). The assertion that no anticompetitive effect was present is suspect. Several commentators have questioned how the refusal to sell to a particular distributor and the blanket prohibition on retail sales can be said to have no anticompelitive effect. See Robinson, supra note 4, at 17 n.106; Zelek, supra note 4, at 39 . The Wella court found that a restraint did exist, but was reasonably ancillary to a legitimate purpose, $425 \mathrm{~F} .2 \mathrm{~d}$ at 938-39. Cases decided after Professional Engineers have not foreclosed a consideration of safety and legal liability concerns. See, e.g., Sports Center, Inc. v. Riddell, Inc., 673 F.2d 786, 791 (5th Cir. 1982) (marketing restraint not unreasonable because of legitimate business reason for limiting product distribution to avoid products liability consequences); see also Neeld v. National Hockey League, 594 F.2d 1297, 1300 (9th Cir. 1979) (league by-law making players with only one eye ineligible not unreasonable because anticompetitive effect is "at most de minimis, . . . and incidental to the primary purpose of promoting safety"); Taylor, Rule of Reason Cases Since National Society of Professional Engineers, 51 ANTITRUST L.J. 185, 194-95 (1982) ("safety, particularly product safety, is still considered important in analyzing agreements where the anticompetitive impact of the agreement is not great").

116. This is essentially the analysis used in the sports association cases. See supra notes 80-81 and accompanying text. It is also essentially a common law ancillary restraint analysis, an approach suggested as appropriate for many rule of reason cases, see infra notes 130-141 and accompanying text. For a discussion of the importance of procedural safeguards, see Kissam, Antitrust Law and Professional Behavior, 62 TEx. L. REv. 1, 44 \& 58-60 (1983). 
weighs the restrictive effect in a more limited market. ${ }^{117}$

\section{Alternative Methods of Analysis}

The Supreme Court's unstinting defense of competition in Professional Engineers and its apparent preclusion of all other factors under the rule of reason presents troublesome analytical hurdles in cases involving unique situations, particularly where self-regulating groups and noneconomic justifications are involved. Despite some of the unrelenting language found in Professional Engineers, the opinion does present several alternative ways by which it could be adapted to special situations.

One of these is found in the Court's continued adherence to the cautionary footnote that first appeared in Goldfarb v. Virginia State Bar. ${ }^{118}$ In this footnote, the Supreme Court suggested that professions differ from other business activities and therefore may be subject to a somewhat different antitrust analysis. The Court stated that due to the public service aspect and other features of the professions, a practice which would be viewed as a violation of the Sherman Act in other contexts may be treated differently. ${ }^{119}$ In Professional Engineers, the Court again

117. The areas that this note focuses on are by no means an exhaustive list of the areas where the Professional Engineers rule of reason may prove troublesome. Another example of a potentially serious problem is found with municipal zoning regulations. The Supreme Court has held that municipalities do not have a blanket exemption from the Sherman Act. See Community Communications Co. v. City of Boulder, 455 U.S. 40, 50-51 (1982). Most zoning regulations restrain competition and have no procompetitive purpose. See Comment, Antitrust and Zoning - How Much Respect for Local Government?, 22 SANTA ClARA L. REv. 901,904 (1982). If the municipalities cannot defend a zoning law on the basis of benefit to the community in terms of health, safety, and welfare-and Professional Engineers seems to say they cannot-it would appear that virtually all zoning laws are candidates for successful antitrust challenges. See Community Communications Co., 455 U.S. at 65-66 (Rehnquist, J., dissenting); Comment, supra, at 908; see also Note, Municipal Antitrust: An Overview, 60 CH1.[-]KENT L. REV. 349, 372 (1984) ("Under the Rule of Reason municipalities will be unable to defend their challenged conduct on the basis of legitimate safety, health, and welfare considerations.").

118. 421 U.S. 773 (1975); see supra note 20.

119. 421 U.S. at 788 n.17. Goldfarb involved the setting of a minimum-fee schedule for specified legal services. Id. at 775. The schedule was published by the Fairfax County Bar Association and enforced by the Virginia State Bar. Before it would provide financing for a home that Goldfarb had contracted to buy, the lender required that a title examination be conducted. Only a member of the Virginia State Bar could legally perform the title examination. Id. When Goldfarb was unable to find a lawyer who would examine the title for a fee less than that prescribed in the mininum-fee schedule, he initiated an action alleging price fixing in violation of section 1 of the Sherman Act. Id. at 778 .

The Supreme Court held that the minimum-fee schedule "constitute[d] a classic illustration of price fixing," $i d$. at 783, and rejected an exclusion from antitrust regulation for the learned professions. Id. at 787 . In so doing, the Court left open the possibility that the professions may be subject to a different antitrust analysis than that imposed on other businesses, because of the public service aspects and other features of the professions: "It would be unrealistic to view the practice of professions as interchangeable with other business activities, and automatically to apply to the professions antitrust concepts which orginated in other areas." Id. at 788 n.17. 
adhered to this view, ${ }^{120}$ although rejecting out of hand the engineers' claim that public welfare would be endangered by competitive bidding on engineering work. ${ }^{121}$

The precise scope of the Goldfarb footnote is still unclear, particularly with regard to whether an ethical rule with an overall anticompetitive effect is necessarily invalid and whether a court may ever consider benefits other than increased competition under the rule of reason. ${ }^{122}$ Despite this uncertainty, a number of courts have concluded that the hospital staff privilege and health care cases provide a proper setting for invocation of the Goldfarb footnote. ${ }^{123}$ In these circumstances, courts have held that if the rule in question is noncommercial, and is intended to serve the public, it can survive a challenge under the antitrust laws. ${ }^{124}$ The fact that the Court is still willing to entertain a somewhat different antitrust analysis reflecting the special circumstances of the professions suggests that this approach may also be available to other entities, particularly where self-regulation is prevalent.

A related possibility is reflected in the Court's use of the language from older rule of reason cases, particularly Chicago Board of Tradev. United States. ${ }^{125}$ Under this often cited formulation of the rule of reason, it is necessary to analyze "the facts peculiar to the business, the history of the restraint, and the reasons why it was imposed." 126 This detailed

120. 435 U.S. at 696. The Court continued to adhere to this view in Arizona v. Maricopa County Medical Soc'y, 457 U.S. 332, $348-49$ (1982). Maricopa County involved the setting of maximum physician fees in coordination with an insurance plan. Id. at 335-36. In condemning this arrangement, the Court noted that it did not involve an ethical norm or public service regulation. Id. at 349 .

121. Id. at 681 (finding that "the asserted defense rests on a fundamental misunderstanding of the Rule of Reason").

122. It was these concerns that led Justices Blackmun and Rehnquist to concur in the Court's judgment, but not join the rule of reason section of the Court's opinion in Professional Engineers. Id. at 699 ; see supra note 35 .

123. See e.g., Kreuzer v. American Academy of Periodontology, 558 F. Supp. 683, 684 (D.D.C. 1983), aff'd in part, rev'd in part, and remanded, 735 F.2d 1479 (D.C. Cir. 1984); Pontius v. Children's Hosp., 552 F. Supp. 1352, 1376 (W.D. Pa. 1982).

124. See Williams v. Kleaveland, 534 F. Supp. 912, 918 (W.D. Mich. 1981) (quoting Boddicker v. Arizona State Dental Ass'n, 549 F.2d 626, 632 (9th Cir.), cert. denied, 434 U.S. 825 (1977)).

125. 246 U.S. 231 (1918). In Chicago Board of Trade, a commodity exchange adopted a rule providing that any trades executed between the close of trading and the opening of the session on the next business day must be executed at the closing bid price. Id. at 237. The rule was challenged as an antitrust violation. The Board defended the rule by contending that its purpose was to promote the convenience of its members by restricting its hours of operation and to break up a monopoly in grain trade held by four or five warehousemen. Id. The Court upheld the rule, finding that it merely restricted the period of price-making, applied only to a small amount of grain traded, and helped improve market conditions by bringing about regular hours, bringing buyers and sellers into more direct contact, and eliminating the risks of a private market. Id. at 239-41. The Court recognizcd the legitimate business need to set hours in which business may be done. Id. at 241 .

126. Professional Eng'rs, 435 U.S. at 692; see Chicago Bd. of Trade, 246 U.S. at 238. 
analysis seems to envision more than a simple weighing of competitive effects. The Court took account of social and business factors other than increased competition in Chicago Board of Trade. ${ }^{127}$ Although the focus of Chicago Board of Trade was on the restraint's effect on competition, the Court admonished that "the legality of an agreement can not be determined by so simple a test, as whether it restrains competition."128 Instead it is necessary to look into all circumstances of the case including the history, peculiar business conditions, and purpose of the restraint. ${ }^{129}$ If the courts are merely to balance competitive effects, it is unclear why there would be any need to explore the history and purpose of a restraint. On the other hand, if the courts are still able to explore market conditions, facts peculiar to the business, and the restraint's purpose, then the rule of reason should retain enough flexibility to accommodate unusual entities and noncommercial restraints. Perhaps the Court did not intend to narrow the rule of reason focus to the extent that portions of Professional Engineers seem to imply.

Another, and perhaps the best, means of alleviating the rigidity of Professional Engineers can be found in the Court's treatment of the classic covenant-not-to-compete case, Mitchel v. Reynolds. ${ }^{130}$ Mitchel involved a promise by the seller of a bakery that he would not compete with his buyer in the bakery business. ${ }^{131}$ The covenant was limited in duration as well as in geographical scope. The Supreme Court cited Mitchel with approval in Professional Engineers as a proper rule of reason decision. ${ }^{132}$

The Professional Engineers Court conceded that the covenant in Mitchel had an anticompetitive effect, as it certainly diminished competition in the bakery business. ${ }^{133}$ The procompetitive justification for the restraint cited by the Court was its enhancement of the marketability of the business, thereby providing incentives to develop such an enterprise, and in the long run benefitting competition. ${ }^{134}$ This is an extremely strained construction of the ancillary restraint doctrine in order to make it consistent with the competitive balancing approach espoused by

127. 246 U.S. at 239-41; see Casenote, National Society of Professional Engineers v. United States, 57 U. DET. J. URB. L. 142, 148-50 (1979); supra note 125.

128. 246 U.S. at 238.

129. Id.

130. I P. Wms. 181, 24 Eng. Rep. 347 (1711).

131. See Professional Eng'rs, 435 U.S. at 688.

132. Id. at 688-89.

133. Id.

134. Id. at 689. 
Professional Engineers. ${ }^{135}$ The long-established method of evaluating a covenant not to compete is to ask whether it is reasonably necessary to effect a legitimate transaction. ${ }^{136}$

The Professional Engineers Court thus seemed willing to sanction a decrease in competition in the bakery market in order to promote larger business and social goals, and, in effect, acknowledged that free and open competition among bakers is sometimes less than desirable. ${ }^{137}$ This position is at odds with other parts of the Professional Engineers opinion, where any abrogation of free and open competition is condemned. Nevertheless, the ancillary restraint doctrine is a useful one, and is capable of rectifying most of the problems identified in this note. ${ }^{138}$

Once it is conceded that a given goal is a legitimate one, the restraints imposed to effect it can be assessed in terms of their reasonable necessity and breadth. This approach would be useful in remedying the specific problem areas addressed by this note. The initial focus on a goal's legitimacy is important in order to accommodate the competing concerns in the antitrust assessment. Our society contains many organizations that do not, and should not, operate solely for commercial purposes. If such organizations are allowed to pursue noncommercial objectives, these objectives cannot be excluded from consideration when the organization is subjected to antitrust accusations. ${ }^{139}$ At the same time, an organization pursuing noncommercial objectives can wield considerable economic and commercial power. ${ }^{140}$ The courts must therefore

135. See Handler \& Lazaroff, Restraint of Trade and the Restatement (Second) of Contracts, 57 N.Y.U. L. REv. 669, 752-55 (1982). Handler and Lazaroff note that lower courts handling typical ancillary restraint cases, such as covenants not to compete, have not adopted the Professional Engineers balancing test. They argue, however, that Professional Engineers cramps the analytical framework and that, if rigidly applied, it would negate most ancillary restraints. Id. at 754-55; see also Robinson, supra note 4, at 17-18 (literal application of Professional Engineers test would call into question ancillary restraints traditionally sustained as reasonable; attempt to harmonize ancillary restraint doctrine within narrow Professional Engineers rule of reason "patently forced").

136. See sources cited supra note 135.

137. 435 U.S. at $688-89$.

138. Using the ancillary restraint doctrine to assist in the difficult area of applying the antitrust laws to professional league sports has been suggested. See Bork, Ancillary Restraints and the Sherman Act, 15 A.B.A. SEC. ANT1TRUST L. 211, 231 (1959); see also National Football League v. North Am. Soccer League, 459 U.S. 1074, 1077-78 (1982) (Rehnquist, J., dissenting from denial of cert.) (conducting ancillary restraint analysis of league rule prohibiting NFL team owner from owning controlling interest in NASL team). The notion that the Sherman Act should be applied with reference to the common-law ancillary restraint doctrine is not novel. See United States v. Addyston Pipe \& Steel Co., 85 F. 271, 279-84 (6th Cir. 1898), aff'd and modified, 175 U.S. 211 (1899).

139. See Gulland, Byrne \& Steinbach, Intercollegiate Athletics and Television Contracts. Beyond Economic Justifications in Antitrust Analysis of Agreements Among Colleges, 52 FORDHAM L. REv. 717,729 (1984) (arguing that "noncommercial values must be given weight in analyzing the practices of noncommercial institutions and organizations that have some commercial consequences").

140. See infra note 154 . 
carefully assess the reasonable necessity and breadth of the challenged restraints. The ancillary restraint doctrine is a vehicle capable of accommodating these competing concerns.

It is submitted that an ancillary restraint approach would be preferable to the use of a strained competitive balancing approach in many situations. It would bring to the forefront the basic concerns and allow a court to assess them in a straightforward fashion. Analytical clarity and logical consistency would follow and the danger of mechanical, inflexible application of the antitrust laws would be lessened. The potential of an ancillary restraint approach is illustrated in the Court's recent treatment of television broadcast rules imposed by the National Collegiate Athletic Association (NCAA). ${ }^{141}$ Although the Supreme Court claimed to follow the rigid Professional Engineers approach, it nevertheless utilized some of the aspects of an ancillary restraint analysis.

\section{A CASE Study: NCAA V. BOARD OF REGENTS}

The court of appeals decision in Board of Regents v. NCAA ${ }^{142}$ is a good example of the problems created by a rigid application of Professional Engineers. NCAA involved a challenge by certain member schools to the NCAA's football television regulations. ${ }^{143}$ The broadcast rules limited schools to a specified number of television exposures, limited the total number of televised games, and effectively set the compensation received by schools for each appearance. ${ }^{144}$ The schools challenging the regulations sought to invalidate the contracts entered into between the NCAA and the television networks and become free to strike their own deal for the sale of broadcast rights to games in which they were to participate. ${ }^{145}$

The district court had held that the NCAA's television regulations were invalid per se as well as unlawful under the rule of reason, ${ }^{146}$ and

141. NCAA v. Board of Regents, 104 S. Ct. 2948 (1984).

142. 707 F.2d 1147 (10th Cir. 1983), aff'd, 104 S. Ct. 2948 (1984).

143. While it was at one time questionable whether the NCAA, as a voluntary, nonprofit organization whose goals are presumably educational, would be subject to the antitrust laws, this issue is no longer in doubt. See Hennessey v. NCAA, 564 F.2d 1136, 1148-49 (5th Cir. 1977) ("The court holds that the NCAA is not entitled to a total exclusion from antitrust regulations . . . ."); see also NCAA v. Board of Regents, 104 S. Ct. 2948, 2954 (1984) (antitrust laws applied to NCAA television broadcast regulations).

144. NCAA, 707 F.2d at $1150,1152$.

145. Id. at 1149.

146. NCAA, 546 F. Supp. 1276, 1311, 1314-15 (W.D. Okla. 1982), aff'd in part and remanded, 707 F.2d 1147 (10th Cir. 1983), aff'd, 104 S. Ct. 2948 (1984). 
the Court of Appeals for the Tenth Circuit affirmed. ${ }^{147}$ The NCAA defended the broadcast rules as necessary to maintain an athletic competitive balance between the schools. ${ }^{148}$ The Tenth Circuit did not believe that it could take such a justification into account. Rather, it cited Professional Engineers for the proposition that "[n]oneconomic considerations, however worthy, cannot be used to justify restraints that adversely affect competition." 149

The full ramifications to the NCAA of this assertion can readily be seen. As the court itself noted, the NCAA is essentially a rulemaking and rule-enforcing body made up of public and private colleges performing mostly noncommercial functions. ${ }^{150}$ It was formed in part to "govern the conduct of its member institutions in the administration of intercollegiate athletics." 151 The NCAA has played a large role in regulating amateur collegiate sports. ${ }^{152}$ It sets eligibility requirements and playing rules, regulates recruiting, determines the length of the season, dictates how many games are played, and specifies the number of coaches a team may have and the number of scholarships a school may offer. ${ }^{153}$ Most, if not all, of these practices can be viewed as restraints of trade.

The NCAA's concern for amateurism and educational goals purportedly lies behind these regulations. ${ }^{154}$ The Tenth Circuit believed that Professional Engineers precluded consideration of noneconomic considerations such as education or amateurism. ${ }^{155}$ If this chain of reasoning is followed, the NCAA would be completely prohibited from functioning within its legitimate sphere. Any regulation with the slight-

147. NCAA, 707 F.2d at 1162 . The Supreme Court held that the NCAA's practices were not illegal per se, $N C A A, 104 \mathrm{~S}$. Ct. at 2960 , but affirmed the lower court holding that the practices violated the rule of reason. Id. at 2971.

148. NCAA, 707 F.2d at $1154,1159$.

149. Id. at 1154 .

150. Id. at 1153 .

151. Hennessey v. NCAA, 564 F.2d 1136, 1141 (5th Cir. 1977).

152. NCAA, 104 S. Ct. at 2954.

153. NCAA, 707 F.2d at 1153 .

154. Although the NCAA is primarily a noncommercial entity, there can be little doubt that collegiate sports have considerable commercial appeal. The NCAA is likely to respond to any charge against it by reference to its concern for education and amateurism. Care must be taken to insure that this concern is not used to defend practices that are, in essence, veiled economic restraints. See Weistart, Legal Accountability and the NCAA, 10 J.C. \& U.L. 167, 175-80 (1983). Instructive in this regard is the NCAA Select Committee's statement regarding the appropriate considerations underlying the college football television policy:

The Committee believes that, regardless of the outcome of current litigation pertaining to the control of televising college football, it is in the decided best interest of intercollegiate athletics that institutions band together and act in concert in matters of this sort, with the objective of generating the maximum possible revenues and achieving the maximum benefits for participating schools.

The NCAA News, Oct. 31, 1983, at 12, col. 3.

155. NCAA, 707 F.2d at 1154 . 
est anticompetitive effect could not be upheld if the only offsetting justification is an educational or amateurism concern-concerns that do not count because they are "noneconomic."

This predicament results from trying to force noncommercial regulations within the Professional Engineers framework that was intended for the commercial world. For example, suppose the NCAA prohibits the staging of athletic events during a time period when all of its member institutions are conducting exams. Two schools may be presented with a lucrative opportunity to face each other in an athletic competition during this time period. These schools may decide to challenge the NCAA's prohibition on antitrust grounds. An anticompetitive effect is apparent, as output has been restricted. A rigid application of Professional Engineers would require an offsetting procompetitive effect to uphold the rule. Applying the Tenth Circuit's reasoning, the NCAA's concern for the student-athlete's uninterrupted exam period could not be considered because it is noneconomic.

A literal application of the Professional Engineers approach asks the wrong questions regarding a regulation of this kind. The inquiry should focus on the legitimacy of the NCAA's educational goal and whether the means intended to implement it are both reasonably related to that goal and not overly restrictive. Conducting a balancing of competitive effects does not provide any real guidance to a court trying to assess such a regulation.

The Supreme Court was presented with an opportunity to clarify the scope of the rule of reason inquiry as applied to noncommercial regulations in NCAA v. Board of Regents. ${ }^{156}$ The drastic possibility suggested by the reasoning of the Tenth Circuit, that the NCAA may never justify its practices by reference to noneconomic factors such as amateurism or educational goals, was probably alleviated by the Supreme Court's decision. The Court's opinion, however, does not identify how these noneconomic concerns are to be incorporated into the antitrust analysis, and ultimately fails to address adequately the role of noneconomic considerations.

The Supreme Court first rejected the imposition of per se illegality, ${ }^{157}$ noting that the case involved an industry in which restraints are "essential if the product is to be available at all." 158 In other words, without joint activity and cooperation the product could not be produced. Further, the Court noted that many of the NCAA's rules were

156. 104 S. Ct. at 2955-57.

157. Id. at 2961.

158. Id. 
aimed at defining the particular product-college or amateur athletics. ${ }^{159}$ This required regulations defining the rules of the game and the size of squads, as well as educational and amateurism rules, such as mandatory class attendance and the prohibition against athletes receiving compensation. ${ }^{160}$ The Court viewed these regulations as "procompetitive" because they allowed for a product that might not otherwise be available. ${ }^{161}$

The Court then conducted a rule of reason analysis to determine whether or not the broadcast restraints enhance competition. ${ }^{162}$ The Court agreed with the district court's finding that the television plan restrains price and output and therefore has an anticompetitive effect. ${ }^{163}$ This placed a heavy burden on the NCAA to establish an affirmative defense. ${ }^{164}$ The Court rejected the NCAA's defense that television restrictions were necessary to protect live gate attendance for two reasons. First, the television plan did not prohibit televised games at the same time as live events. ${ }^{165}$ Second, the Court characterized this defense as an argument that competition is unsuitable for the industry. ${ }^{166}$ Professional Engineers was cited for its proposition that the rule of reason does not support a defense based on the unreasonableness of competition itself. 167

The Court then turned to the NCAA's defense that the plan was necessary to maintain a competitive balance among the athletic teams. The Court agreed that this was a legitimate and important interest, but concluded that it did not justify the restrictions imposed. ${ }^{168}$ In essence, the Court found that the television plan was "not even arguably tailored" to serve the interest of competitive balance and certainly was overbroad to serve such an interest. 169

The Court purported to retain the rule of reason formulation set out by Professional Engineers-asking "whether or not the challenged restraint enhances competition." 170 However, in evaluating the NCAA's defense that the television rules are needed to maintain competitive balance among the college teams, the Court came very close to applying the ancillary restraint test that this note suggests is appropriate for evaluat-
159. Id.
160. Id.
161. Id.
162. Id. at 2962.
163. Id. at 2962-63.
164. Id. at 2967.
165. Id. at 2968.
166. Id. at 2969.
167. Id.
168. Id. at 2969-70.
169. Id. at 2970.
170. Id. at 2962. 
ing the noneconomic restraints of a self-regulatory body. ${ }^{171}$ The Court initially conceded that the NCAA's interest in competitive balance was a legitimate one. ${ }^{172}$ It then proceeded to analyze the restraint to determine whether the television rules were necessary to achieve such a result. ${ }^{173}$ After evaluating the facts, the Court rejected the notion that the television plan was intended to promote competitive balance. ${ }^{174}$ The Court noted that other methods used by the NCAA to promote amateurism and athletic balance were better suited to such a task and were "clearly sufficient" to accomplish it. ${ }^{175}$ Further, other NCAA sports, including college basketball, were able to maintain competitive balance without a restrictive television plan. ${ }^{176}$ The Supreme Court assessed the legitimacy of the activity, whether the restraint imposed was reasonably necessary, and whether it was overbroad.

In the section of the Court's opinion that is crucial for determining how other NCAA noneconomic regulations should be evaluated in the future, the Court stated that it is "reasonable to assume that most of the regulatory controls of the NCAA are justifiable means of fostering competition among amateur athletic teams and therefore procompetitive because they enhance public interest in intercollegiate athletics."177 The Court referred to its reasons for refusing to apply the per se rule ${ }^{178}$ - the need for cooperative activity and rules in order to create the product-as valid considerations in the rule of reason analysis. ${ }^{179}$ The television broadcast restraints, however, were said not to "fit into the same mold as do rules defining the conditions of the contest, the eligibility of participants, or the manner in which members of a joint enterprise shall share the responsibilities and the benefits of the total venture." 180

The Court's discussion suggests several important points. The court of appeals' argument that noneconomic justifications can never be considered $^{181}$ can no longer be viewed as an absolute. The Supreme Court recognized the legitimacy of a concern for athletic balance and for regulations necessary to define a product requiring a cooperative undertak-

171. See supra notes $116,130-41$ and accompanying text.

172. NCAA, 104 S. Ct. at 2969.

173. Id. at $2969-70$.

174. Id.

175. $I d$.

176. Id.

177. Id. at 2969.

178. See supra notes 157-61 and accompanying text.

179. NCAA, $104 \mathrm{~S}$. Ct. at 2969.

180. Id.

181. See NCAA, 707 F.2d at 1154. 
ing. ${ }^{182}$ Although it did not explain how such concerns should be evaluated, the Court's opinion provides language sufficient to dispel the notion that these concerns are never cognizable. ${ }^{183}$

Nevertheless, the Court's opinion fails to provide useful guidance for assessing noneconomic justifications. The Court held unlawful the NCAA's very restrictive television broadcast rules, an obviously commercial restraint, but appeared willing to sanction all of the NCAA's regulatory controls intended to foster amateurism. The Court's statement that it is "reasonable to assume" that most of the NCAA's regulatory controls are justifiable is a particularly troublesome assertion. ${ }^{184}$ The examples used by the Court as appropriate instances of NCAA conduct are broad and provide no inherent limitations. These examples include defining the conditions of the contest, the eligibility of participants, or the manner in which members of the joint enterprise share the responsibilities and benefits. ${ }^{185}$ The NCAA can be expected to assert this type of justification for any of its practices that are challenged.

The danger of upholding any rule that arguably promotes amateurism because of the legitimate regulatory role of the NCAA is exemplified by the dissent in NCAA. Justice White's dissent emphasized the noneconomic nature of the NCAA's self-regulation. He noted that the Sherman Act was aimed at activities of a commercial nature and believed that the nonprofit aspect of the NCAA and the noneconomic nature of the goals it was pursuing argued for different treatment. ${ }^{186}$ Justice White asserted that Professional Engineers' mandate to focus solely on competition was applicable only to "profit-motivated commercial activities."187 He did not believe that Professional Engineers precluded consideration of

182. NCAA, $104 \mathrm{~S}$. Ct. at 2969 . One point that merits further emphasis in analyzing the decision in NCAA is the majority's treatment of the NCAA's need for cooperative activity and joint rulemaking in order to produce the product. This factor is cited as a ground for refusing to apply the per se rule, $i d$. at 2961-62, and is the reason given by the Court for its statement that it is "reasonablc to assume" that most of the NCAA's regulations are justifiable. Id. at 2969. The need for cooperative activity could just as easily be characterized as an argument that competition is undesirablc because of special industry characteristics. This illustrates that a court's characterization of a proferred justification as an argument that "competition is undesirable" is a chameleon-like response-one that can change to fit the needs of the proponent.

183. See Justice White's dissent, stating that the "legitimate noneconomic goals of colleges and universities should not be ignored in analyzing restraints," noting that the court of appeals "flatly refused to consider" such justifications, and stating that at least the Supreme Court did not "in so many words repeat this error." NCAA, 104 S. Ct. at 2978 (White, J., dissenting).

184. Id. at 2969.

185. Id.

186. Id. at 2978 (White, J., dissenting).

187. Id. (White, J., dissenting). 
noneconomic values. 188 Justice White's attempt to factor the noneconomic values into the balance is very problematic. He summarily concluded that the television plan "seems eminently reasonable" when these values are considered. ${ }^{189}$ This conclusion was apparently premised on the fact that spreading revenue among the schools fosters amateurism and competitive balance. 190 No attempt was made to determine if the television plan was necessary to accomplish these goals, whether less restrictive means were available, or whether the television plan was broader than it had to be. Instead the dissent accepted the NCAA's justification without rigorous analysis.

By continuing to adhere to the competitive balancing approach espoused by Professional Engineers, the Court did little to promote clarity of analysis in the future. On the one hand, the Court continued to require that a challenged restraint be on balance "procompetitive."191 On the other hand, the Court appeared willing to assume the legitimacy of most NCAA regulations because they help to define and make possible the product. 192 When faced with an NCAA regulation that has more than a trivial anticompetitive effect, but which could also be justified as helping to define and make possible the product of amateur athletics, the lower courts will find little guidance in NCAA or Professional Engineers. ${ }^{193}$ These cases are unlikely to be the last words on how noneconomic concerns should fit into the rule of reason.

\section{CONCLUSION}

In National Society of Professional Engineers v. United States 194 the Supreme Court undertook a review and restatement of the rule of reason. The approach taken by the Court eliminated much of the flexibility traditionally associated with the rule of reason, making its application difficult in unique situations. Although parts of the opinion enunciate a very rigid rule of reason, the Court left open several avenues that are capable of restoring the necessary flexibility. The Court's reference to the common-law ancillary restraint doctrine is a particularly promising means of

188. Id. (White, J., dissenting); see also Gulland, Byrne \& Steinbach, supra note 139, at 727-29 (arguing that Professional Engineers' focus on economic competition and its preclusion of noneconomic factors was only meant to apply to for-profit businesses).

189. NCAA, 104 S. Ct. at 2978 (White, J., dissenting).

190. Id. (White, J., dissenting).

191. Id. at 2962.

192. Id. at $2968-69$.

193. See Gulland, Byrne \& Steinbach, supra note 139, at 729 ("The insistence on conducting an analysis of college athletic regulations solely in the cant of economic antitrust analysis produces incongruous statements and murky thinking clothed with the false precision of jargon.").

194. 435 U.S. 679 (1978). 
accommodating the antitrust laws to unique situations. The Court took steps towards employing such an analysis in NCAA v. Board of Regents, ${ }^{195}$ but also purported to adhere to the narrow formulation of Professional Engineers. A more satisfying approach to the rule of reason would result if the Court were to adopt explicitly the alternatives suggested in Professional Engineers.

Barry Wertheimer

195. 104 S. Ct. 2948 (1984). 